\title{
UK HIGHER EDUCATION AND BREXIT
}

\section{KEN MAYHEW}

\section{Introduction}

The vote to leave the EU in the June Referendum caused great consternation in higher education circles. Universities UK (UUK), the Russell Group, the MillionPlus group and other HE groupings had all expressed strong support for a Remain vote. Though there were a few dissenters, for example Lee Jones and Chris Bickerton (2016) who described the UUK's stance as Project Fear, most academic voices sounded concern and in some cases near panic. However, this is not a narrow parochial issue. HE is a major exporter. A UUK report (2015) estimated that the sector accounted for $€ 10.71$ billion of export earnings in 2011 about 10 per cent of the UK's total exports of services. Furthermore it is a key strategic asset for the economy, with spin-offs from its research activities critical for innovation. Universities are often key employers in the local economies in which they are located. The same UUK report claimed that, taking into account multiplier effects, HE generated $£ 73$ billion of output in 2011-12, or 2.8\% of GDP. It accounted for $2.7 \%$ of the country's employment. Thus, when in the immediate aftermath of the Referendum result, UUK urged the government to develop policies to "support universities to thrive post exit" it was making statement of national and not just sectoral importance. UUK's pleas were to:

1. "Support and enhance UK's international research collaborations";

2. "Support to ensure UK is an attractive destination for talent";

3. "Increase public investment in the research base";

4. "Support for students and staff to access vital global opportunities". 
As with everything else concerned with BREXIT there is massive uncertainty as to what eventual outcomes will be, but, underlying the UUK's pleas, are several areas of threat. They are:

- The implications of BREXIT for the number of EU students studying in the UK and the potential consequences for university revenues.

- The impact of exit on UK universities' access to EU research funding

- The impact on the ability of UK universities to hire and retain staff from EU countries.

- The impact on the ability of UK students to study abroad.

Before exploring each of these threats in turn, it is important to note the more general background on immigration. It is the Government's declared intent to reduce migration (from whatever country of origin) to the UK, and there have recently been a variety of government announcements about how they might set about doing this. Significantly the UK authorities insist on including students in the inward migration figures (in recent years they have accounted for about $30 \%$ of the total).

\section{EU students studying in the UK}

In 2014/15 23\% of all full-time HE students were foreign. For full time taught higher degrees the percentage rose to just over 70, whilst for research higher degrees it was 50 per cent. Amongst these, EU students represented 5.3\% of full time undergraduates, $12 \%$ of taught Masters students and $14.3 \%$ of doctoral students.

There has been an increasing reliance on EU undergraduates in recent years given UK demographics and a slowdown in 
applications from non-EU students. In the latest admissions round lower ranking universities appear to have been particularly squeezed in both respects. Furthermore there has been a slight fall in EU entrants this autumn.

EU students have been coming here despite the fact that they would have had to pay less for their courses in most, if not all, other EU countries. The worry is that if they were required to pay the full international students' fee, then a significant proportion of them would be deterred. The Government and the universities themselves have taken some steps to alleviate shorter-term worries. The universities have reassured EU students already on course that they will be charged only EU fees for the duration of their courses and have given similar assurances to potential entrants in 2017. The Government has also announced that EU students currently on course in English universities and those starting in 2017 will continue to have access to existing funding and loan support arrangements. For the longer term, concern about fees may be unwarranted. As far as I can see, there is nothing fundamental to prevent UK universities continuing to charge the domestic fee to EU citizens. But, as things stand, EU students would no longer be eligible for loans to cover their fees from the Student Loan Company. A the same time they would be subject to the complex and expensive visa requirements currently experienced by non-EU foreigners. Obviously these two matters are out of the control of universities and are a matter of government policy. Some EU students come to the UK with the intention of remaining here to work after completing their studies and others come entertaining that possibility. Depending on what is negotiated regarding freedom of movement more generally, this pull factor may disappear or be significantly reduced. 
And the percentages given above are averages; some universities are much more exposed than others, as are some subjects. In the most recent year for which I could get reliable figures $13 \%$ of full time undergraduates and postgraduates at UCL were from the EU. The comparable figure for LSE was $18 \%$ and for Imperial and SOAS was $16 \%$. EU students were $25.5 \%$ of full time taught postgrads at LSE and $29.8 \%$ at St Andrews. Indeed the Scottish university sector as a whole seems particularly vulnerable, with $10.5 \%$ of its undergraduates, $24.3 \%$ of its taught postgraduates and $26.2 \%$ of its research postgraduates from EU countries. For the UK as a whole $23 \%$ of those studying Law at the taught postgrad level came from the EU, as did $15.8 \%$ of those studying Maths, 14.6 of those studying Languages and 14.5\% of those studying engineering.

Early indications are not reassuring. Possible because EU students have been deterred by uncertainty and/or by perceptions of a hostile climate, applications for entry to medicine, dentistry and veterinary science as well as for Oxbridge, which closed on 11 October, showed a fall of $9 \%$ from the EU. This was only a few days before that the Government announced that EU students starting their courses in 2017 would continue to have access to funding on present terms. Had this announcement come earlier, the fall might not have been so great.

\section{UK universities' access to EU funding}

What is finally decided about freedom of movement could be even more critical for the future of research funding from the EU. Whilst UK academics still collaborate more with US researchers than with those in Continental Europe, collaborations with the latter have been growing faster. However, it is not clear now much of this collaboration is dependent on EU funding (Royal Society, 2016). Certainly some well-established joint European ventures are 
independent of it - for example, The Open Research Area in the social sciences.

There are two main sources of research funding from the EU - Framework Programmes (FP) and structural funds. It is the former that are overwhelmingly the more important for the UK. And the UK has been a particularly successful bidder. It has obtained over $15 \%$ of FP 7 awards and $20 \%$ of European Research Council awards. Overall the country has received more funds from EU research budgets than its contribution to the overall EU budget might warrant. It is estimated that UK universities get between 2.5 and 3 per cent of their total annual income from EU research and development funding, accounting for about 16 per cent of their research income.

Again, the loss of this source of funding would appear to imply more serious consequences for some universities and subjects than for others, whilst letters in THE claimed that almost three quarters of the increase in HEI science funding between 2007 and 2014 came from EU sources. UK scientists have the additional worry about the location of collaborative capital investments funded in part or whole by Commission monies - for example the JET facilities (Eurofusion) at Culham.

However it is important to note that non-EU countries currently benefit from Framework funding - though, for an ERC award, the research has to be undertaken within an EU or Associate country. 15 non-EU countries currently take part in Horizon 2020, including those that are within the single market as participants in the European Economic Area (EEA) and/or the European Free Trade Area (EFTA) and therefore subscribe to freedom of movement. But there are also participating countries that remain outside the single market and do not allow complete freedom of movement. In other words there is no single associate 
model. What is clear is that our negotiators would have to agree to a financial contribution (and that contribution could well be higher than that currently made by the UK), as is the case for other associate members. What is less clear is the impact that the politics of the BREXIT negotiations and the defensive reactions of some other EU states will have on attitudes towards freedom of movement in achieving a deal. The recent difficulties experienced by Switzerland after its referendum in favour of restricting mass migration might well provide a salutary lesson for the UK.

The UK government has underwritten research contracts granted under EU funding up until the point the UK leaves the EU. Though this has been welcomed, doubts continue to be expressed as to whether, in this period of uncertainty, our Continental colleagues will be willing to participate in joint bids. If this turns out to be the case, there could be lingering effects on such collaborations even if a satisfactory settlement about access to funding is reached by our negotiators.

\section{The academic workforce}

At least if one looks at the percentages, there are reasons to worry about the fate of the academic workforce, $16 \%$ of which is accounted for by EU nationals. By comparison $12 \%$ are non-EU nationals. In the extreme case the future could see EU job applicants being treated in just the same manner as the latter group. However, it is far from clear to me how much difficulty UK universities have experienced historically with the immigration authorities in hiring this group of people. My impression is relatively little, at least until recently, though visa and associated costs have increased significantly in recent years, whilst The Times Higher Education Supplement and other journals carry tales of extreme difficulties experienced by some individuals (see, for example, THE, 5 January 2014). Perhaps the main worry 
here relates to the general immigration policy background, to which I will return. Perhaps also young post-docs, who until now have taken on two or three year fixed term contracts, partly in the hope that this would lead to further employment in the UK, might find the initial contract offers them less attractive prospects for the future. An ideal solution would be a deal that maintained freedom of movement for university staff. Otherwise a general toughening of immigration policy could have severe effects.

Meanwhile will potential EU job applicants be deterred by perceptions of a hostile climate? Will EU members of staff be more likely to leave and seek jobs on the Continent or in the US? Will other members of staff, discouraged by research funding uncertainties and worried by potential difficulties in maintaining or securing European collaborations, look for employment abroad? The pages of THE have been replete with examples of academics contemplating applying for positions abroad and with some examples of them actually taking them.

\section{UK Students Abroad}

UK students have benefited from the Erasmus and subsequently Erasmus Plus programmes - just over 15,000 of them in 2013/14, for example. There seems to be little reason why the UK could not continue to participate. Currently there are programme countries and partner countries, with the latter being accorded limited membership. There are 23 countries that are partners. Programme members include Macedonia, Iceland, Turkey, Liechtenstein and Norway as well as EU member countries. There are problems with the scheme - finding sufficient placements for Modern Languages students, for example but these difficulties are quite independent of BREXIT. It is also important to emphasise that at least as many British 
students spend exchange time abroad quite independently of EU arrangements.

Though at the moment only relatively small numbers are involved, there has been a discernible trend for UK students to take bachelors courses in continental EU countries, often attracted by significantly lower fees. After BREXIT, and like continental students in the UK, they could be facing the higher fees applying to non-EU students. This again will, at least in part, be in the hands of the universities concerned. Such is the desire of many continental universities to internationalise their student bodies that they may continue to charge the lower fees. Furthermore in many countries the gap between the EU fee and the foreign fee is much smaller than in the UK. However some governments and politicians, for example in the Netherlands, have started to question the extent to which they have been subsidizing students from other countries.

\section{Immigration Policy}

Complicating the picture is the fact the Referendum result has coincided with the prospect of a general tightening of immigration policy (for more detail see Portes, 2016). And, as we have seen, the Government insists on including students in the overall immigration figures. On this basis, students from outside the EU have recently accounted for 160,000 of 600,000 new immigrants in a single year. Home Secretary Amber Rudd has issued a consultation paper which suggests the possibility of new immigration rules for foreign students. It is possible that the severity of these rules will be linked to the perceived quality of institutions and of course content. As Ms Rudd said at last Autumn's Tory Party conference: "[we] will ask 'what more can we do to support our best universities - and those that stick to the rules - to attract the best talent?', while looking at tougher rules for students on lower quality courses". Indeed an 
"experiment" has already been put in place. In July a two year pilot was announced that eased visa rules for Masters students at Bath, Cambridge, Imperial and Oxford. The universities concerned will be responsible for eligibility checks and it is thought that this will reduce the documentation necessary to obtain a Tier 4 visa. And students will be allowed to stay in the UK for six months after the completion of their studies to try to find a job that qualifies them for a Tier 2 visa.

So this offers potentially good news for some universities but not for others. The consultation document also raises the spectre of a possible tightening of the resident labour market test, which could have implications for the recruitment of non-UK academic staff.

\section{The Higher Education White Paper}

The developments described above have coincided with last year's HE White Paper, Success as a Knowledge Economy: Teaching Excellence, Social Mobility and Student Choice, which has undoubtedly increased the discomfort of many in the university sector. The proposed Office for Students, set to replace OFFA and HEFCE, is being seen as a potentially more powerful and draconian regulator and there is also concern that, in effect, universities might find themselves under greater direct government control than has been the case until now. A similar concern has been expressed by some academics over the creation of UK Research and Innovation (UKRI), under which the present set of research councils would be subsumed and which would have control of block funding. The government has stressed that the Office for Students would be expected to encourage far greater competition in the sector, with requirement for entry being eased and the role of the Privy Council in granting degree - awarding powers being removed. 
Taken together with official suggestions that immigration controls might be applied differentially across the HE sector, the threat of more rapid entry into the sector by competitors, and the fear that new entrants could offer cheaper courses (quite possibly by more intensive use of online learning), poses a threat to lower ranking universities They see themselves facing the prospect of labouring under a two tier HE system.

\section{Conclusions and Policy Proposals}

It is important to recognize that the international reach of UK universities, both in terms of teaching and research, extends far beyond the EU countries. Nevertheless the anxieties expressed by HE leaders about the potential consequences of BREXIT are understandable, faced as they are by what they see as the perfect storm of departure from the EU, tougher immigration policy and the HE White Paper. It is possible to take an optimistic view about research funding, academic staff, and student mobility. Some measures, most importantly the setting of fees, are in the hands of the universities themselves. Others depend on our negotiators. Perhaps the best scenario is one where a sectoral agreement can be reached for universities. This would allow freedom of movement within the sector, with the prize of good access to European funding. It would make special arrangements for EU staff, imposing no visa requirements or resident labour market tests at the recruitment stage, and for students, both in terms of fees and access to loan support. Any such arrangements for staff and students would of course need to attract reciprocity from EU member states. Short of a whole sector agreement, our negotiators should be aimed for the best possible associate status in Framework and other EU funding programmes. 
However the prospect of a good settlement could get badly compromised by disputes and disagreements in the negotiations about free movement of labour more generally. At the same time the Government seems determined to restrict freedom of movement at least for a proportion of potential students. This poses a real threat to some of our lower ranking HE institutions and goes beyond the specific dangers of BREXIT. It is hard to see why the government insists on continuing to count student entry within our immigration figures and targets. The origin of this attitude would appear to be historical concern about foreigners entering to register for bogus or semi-bogus courses (usually in non-HE institutions) and then illegally working or simply "disappearing" and effectively becoming illegal immigrants. However, these abuses appear to have largely dealt with. Nevertheless the government seems determined to contemplate a two tier system. Even if officialdom cannot be dissuaded from this course of action, this would not be inconsistent with allowing generous entry and post-study arrangements for EU students as part of the larger negotiated package suggested above. If government believes that our university sector needs to be exposed to greater competition from actual and potential entrants, this aim could be achieved by the provisions of the White Paper without the necessity of restrictions on EU students and staff.

Whilst the longer term outcomes remain inevitably uncertain, rather more could be done to ease shorter term concerns. The government's underwriting of all research collaborations concluded before the point of exit from the EU is welcome. Further reassurance could be given by extending the guarantees about fees and funding to EU students admitted before exit.

\section{References}


Jones, L., and Bickerton, C. 2016. "UUK's weak anti-BREXIT case ignores that our fate is for us to decide", The Times Higher Education Supplement, 16 June.

Portes, J. 2016. "Immigration after BREXIT", National Institute Economic Review, November.

Royal Society. 2016. UK Research and the European Union: the Role of the EU in Funding UK Research.

Universities UK. 2015. The Impact of Universities on the UK Economy, London: UUK. 